\title{
BATAS MARITIM INDONESIA DAN PALAU DI ZONA EKONOMI EKSKLUSIF
}

\author{
Ida Kurnia ${ }^{1}$ \\ ${ }^{1}$ Program Studi Ilmu Hukum, Universitas Tarumanagara Jakarta \\ Email:idah@fh.untar.ac.id
}

Masuk : 15-04-2021, revisi: 03-05-2021, diterima untuk diterbitkan : 29-05-2021

\begin{abstract}
Indonesia is bordered by 10 countries, one of which is Palau. Indonesia has the right to the living natural resources in EEZ. As for the width of the EEZ a country can claim up to 200 miles. If the EEZ overlaps with other countries, one of which is Indonesia and Palau, namely using the principle of justice and followed up by making an agreement on the boundaries jurisdiction area. The goal is to have arrangements in use that are believed to be able to maintain the sustainability of living resources based on an agreement. The results show that the clarity of Indonesia's maritime boundaries has an impact on the use of its natural resources. The clarity of maritime boundaries provides the welfare of the Indonesian people, so it can be concluded that the determination of maritime boundaries between Indonesia and Palau will be sought immediately by referring to regulations and success in practices that have been carried out by Indonesia. While the determination of territorial boundaries has not reached an agreement or agreement that is final in nature, both Indonesia and Palau are obliged to follow dispute resolution procedures, according to Chapter XV UNCLOS 1982. UNCLOS 1982 also provides favorable arrangements for the parties concerned, namely during the waiting period / effort. in reaching the final arrangement, especially the regulation of biological resources in the border area, the biological resources can be utilized by implementing temporary arrangements. The research method used is the normative method by examining the related rules.
\end{abstract}

Keywords: Maritime Boundary, ZEE of Indonesia, Palau.

\begin{abstract}
ABSTRAK
Negara Indonesia berbatasan dengan 10 negara, salah satunya dengan Palau. Perbatasan maritim di ZEE Indonesia, Indonesia mempunyai hak atas sumber daya alam hayati yang terdapat di dalamnya. Adapun lebar ZEE suatu negara dapat mengklaim sampai 200 mil. Namun apabila wilayah yurisdiksi dalam hal ini ZEE tumpang tindih dengan negara lain, salah satunya Indonesia dengan Palau, maka harus dibagi sesuai ketentuan yang diatur dalam UNCLOS 1982, yaitu menggunakan prinsip keadilan dan ditindaklanjuti dengan membuat perjanjian tentang batas wilayah yurisdiksi. Tujuannya adalah adanya pengaturan dalam pemanfaatan yang diyakini dapat menjaga keberlanjutan sumber daya hayati yang didasarkan pada perjanjian. Hasil penelitian menunjukkan kejelasan batas wilayah maritim Indonesia berimbas pada pemanfaatan sumber daya alamnya. Kejelasan batas maritim memberikan kesejahteraan rakyat Indonesia, maka dapat disimpulkan penetapan batas maritim antara Indonesia dengan Palau segera diupayakan dengan mengacu pada peraturan dan keberhasilan dalam praktik-praktik yang telah dilakukan oleh Indonesia. Sementara penentuan batas wilayah belum tercapai kata sepakat atau perjanjian yang sifatnya final, baik Indonesia maupun Palau, wajib mengikuti prosedur penyelesaian sengketa, sesuai Bab XV UNCLOS 1982. UNCLOS 1982 juga memberikan pengaturan yang menguntungkan bagi pihak-pihak terkait, yaitu dalam masa tunggu/upaya dalam mencapai pengaturan final, terutama pengaturan sumber daya hayati di wilayah perbatasan tersebut, maka sumber daya hayati dapat dimanfaatkan dengan dilakukan pengaturan sementara. Metode penelitian yang digunakan adalah metode normatif dengan mengkaji aturan-aturan yang terkait.
\end{abstract}

Kata Kunci: Batas Maritim, ZEE Indonesia, Palau

\section{PENDAHULUAN}

\section{Latar Belakang}

Indonesia merupakan salah satu negara kepulauan yang berbatasan dengan 10 negara tetangga, yaitu India, Thailand, Malaysia, Singapura, Vietnam, Filipina, Palau, Papua Nugini, Timor Leste dan Australia. Sebagai negara tentunya perlu kejelasan terkait dengan wilayahnya, sehingga Indonesia perlu menetapkan batas-batas wilayah baik wilayah yang masuk ke dalam wilayah kedaulatan Indonesia maupun wilayah yang masuk ke dalam wilayah yurisdiksi Indonesia. Hal ini supaya Indonesia jelas dalam melaksanakan kedaulatannya dan yurisdiksinya. Jadi tidak hanya 
semata-mata untuk kepastian wilayah saja, namun juga perlu untuk mendapatkan pengakuan dari negara lain. Dalam rangka usaha untuk memperoleh pengakuan tersebut, Indonesia telah menetapkan prinsip yang kemudian dituangkan dalam Undang- Undang Dasar 1945 (UUD 1945). Selanjutnya, secara konkrit pada tahun 1957 Indonesia mendeklarasikan penyatuan wilayah Indonesia melalui Deklarasi Djuanda 13 Desember 1957, yang berbunyi: daratan Indonesia disatukan oleh air (maksudnya laut) dan dibulatkan oleh udara di atasnya. Artinya, Indonesia menyatakan kepada dunia bahwa laut Indonesia adalah termasuk laut di sekitar, di antara dan di dalam kepulauan Indonesia menjadi satu kesatuan, yaitu wilayah Negara Kesatuan Republik Indonesia.

Ketentuan yang tercantum dalam Pasal 1 ayat (1) UUD 1945 menetapkan bahwa bentuk Negara Indonesia adalah suatu Negara Kesatuan. Hal ini mengisyaratkan dan menegaskan bahwa Indonesia adalah suatu negara yang wilayahnya utuh dan tidak terkotak-kotak, serta tidak ada wilayah yang merupakan wilayah internasional yang membagi wilayah Negara Indonesia (seperti pada saat Negara Indonesia dijajah oleh Pemerintah Belanda dan menerapkan pengaturan hukum laut dengan menggunakan aturan yang dibuat oleh Pemerintah Belanda, yaitu Territoriale Zee en Maritieme Kringen Ordonansi 1939 atau biasa disebut TZMKO 1939). TZMKO 1939 menyatakan bahwa pulau-pulau yang berada di wilayah Nusantara dipisahkan oleh laut di sekelilingnya dan setiap pulau hanya mempunyai laut selebar 3 mil dari garis pantai. Selanjutnya, setelah UUD 1945 diamandemen, yaitu seperti yang diatur dalam Pasal 25A UUD 1945, menetapkan bahwa: "Negara Kesatuan Republik Indonesia adalah sebuah Negara Kepulauan yang berciri Nusantara dengan wilayah yang batas-batas dan hak-haknya ditetapkan dengan undang-undang." Berdasarkan amandemen tersebut terkait dengan peraturan perundang-undangan yang telah disiapkan oleh Indonesia, memberikan definisi negara kepulauan berpedoman pada aturan yang telah dituangkan dalam Undang-Undang Nomor 6 Tahun 1966 tentang Perairan Indonesia dan penetapan ketentuan wilayah Negara Indonesia diatur dalam Undang-Undang Nomor 43 Tahun 2008 tentang Wilayah Indonesia.

Dalam tataran hukum Negara Indonesia telah menyiapkan aturan, baik yang terkait dengan penentuan batas terluar wilayah di laut suatu negara yang masuk ke dalam wilayah kedaulatan Negara Indonesia maupun wilayah yang masuk ke dalam wilayah yurisdiksi Negara Indonesia. Artinya bahwa dalam tataran hukum wilayah laut Negara Indonesia baik yang termasuk wilayah kedaulatan Negara Indonesia dan wilayah yurisdiksi Negara Indonesia dalam tataran hukum internasional maupun hukum nasional dapat dikatakan memadai. Namun, dalam implementasinya kelihatannya belum sepenuhnya dijadikan agenda pembahasan yang pokok oleh pemerintah. Mengapa demikian, karena Indonesia sudah meratifikasi United Nations Convention on The Law of The Sea 1982 atau yang disingkat dengan UNCLOS 1982. Pengaturan di dalam UNCLOS 1982 telah menetapkan bagaimana suatu negara menetapkan batas wilayah kedaulatannya dan wilayah yurisdiksinya, termasuk cara-cara penarikan garis batas wilayah kedaulatan dan wilayah yurisdiksi apabila suatu negara berhadapan atau berdampingan dengan negara lain, seperti Negara Indonesia yang berbatasan dengan Negara Palau.

Berdasarkan ketentuan internasional (UNCLOS, 1982) dan ketentuan nasional (Undang-undang Nomor 17 Tahun 1985 Tentang Pengesahan UNCLOS, 1982), luas Perairan Indonesia mencapai 3.25 juta $\mathrm{km}^{2}$ dengan perincian luas Laut Teritorial 0.3 juta $\mathrm{km}^{2}$ dan luas Perairan Kepulauan 2.95 juta $\mathrm{km}^{2}$. Luas Perairan Zona Ekonomi Eksklusif (ZEE) mencapai 2.55 juta $\mathrm{km}^{2}$. Sehingga total keseluruhan luas wilayah yang termasuk ke dalam kedaulatan dan wilayah yang termasuk ke dalam yurisdiksi negara mencapai 3.25 juta $\mathrm{km}^{2}+2.55$ juta $\mathrm{km}^{2}=5.80$ juta $\mathrm{km}^{2}$. Panjang garis pantainya mencapai panjang $81.000 \mathrm{~km}$ dan menurut Keputusan MENHANKAM Nomor 
B/858/M/IX/1987: Dishidros tahun 1982 menghitung pulau dan telah diterbitkan dalam buku jumlah pulau di Indonesia yaitu jumlah pulau 17.508, bernama 5.707 dan tak bernama 11,801. Selain itu, apabila dikaji lebih lanjut maka laut itu tidak hanya sekedar sebagai jalur pelayaran saja, akan tetapi laut itu dapat dikatakan hidup, artinya bahwa di dalamnya terdapat keanekaragaman sumber daya alam hayati, artinya sumber daya alam yang sifatnya hidup. Bahkan di laut tidak hanya terdapat sumber daya alam yang hayati saja akan tetapi juga terdapat sumber daya alam yang mati atau yang sifatnya non-renewable (tidak dapat diperbaharui/ sumber tersebut untuk ada lagi dan bisa dimanfaatkan membutuhkan waktu yang relatif lama, misal 100 tahun bahkan lebih). Dengan demikian sumber daya alam yang terdapat di laut perlu diatur penggunaannya, baik yang sifatnya renewable (dapat diperbaharui) maupun sumber daya alam yang sifatnya tidak dapat diperbaharui. Sumber daya alam tersebut terdapat baik di wilayah yang termasuk dalam kedaulatan suatu negara maupun terdapat di wilayah yurisdiksi. Dari sinilah laut mempunyai arti kesatuan wilayah yang memiliki 2 (dua) aspek utama, yaitu aspek security (keamanan) dan aspek prosperity (kesejahteraan), sehingga penetapan batas terluar dan garis batas wilayah yang termasuk wilayah kedaulatan dan garis batas wilayah yang termasuk wilayah yurisdiksi negara di laut dengan negara-negara yang bersebelahan ataupun yang berbatasan perlu diwujudkan dalam rangka memperoleh kepastian hukum yang dapat menunjang berbagai kegiatan di laut.

Negara Indonesia yang merupakan Negara Kepulauan yang tergolong terbesar dan telah ditegaskan di atas bahwa Indonesia telah meratifikasi UNCLOS 1982, maka Indonesia dalam rangka menjaga wilayah kedaulatannya dan wilayah yurisdiksinya seharusnya sudah siap dengan aturan-aturan yang terkait dengan batas-batas dengan negara lain terutama batas yang terkait dengan kesejahteraan, yaitu batas ZEE Indonesia. Hal ini dilandasi bahwa pada kenyataannya jumlah penduduk Indonesia bertambah cukup signifikan dan sumber daya alam yang terdapat di darat makin berkurang bahkan habis, sehingga sumber daya alam yang terdapat di laut khususnya di ZEE Indonesia perlu dimanfaatkan/dipergunakan untuk mencadangkan sumber daya perikanan bagi kepentingan Rakyat Indonesia. Namun pada kenyataannya pemanfaatan sumber daya alam hayati yang terdapat di ZEE Indonesia dapat dikatakan belum dapat sepenuhnya dimanfaatkan oleh rakyat Indonesia, salah satu yang menjadi permasalahannya adalah belum adanya batas ZEE Indonesia dengan negara lain.

Indonesia harus segera mengambil langkah, salah satunya dengan mengkaji keberhasilan negaranegara lain dalam rangka menetapkan batas ZEEnya dengan negara yang bersebelahan atau berhadapan. Selanjutnya, hal yang perlu dicermati adalah melihat kembali perjanjian-perjanjian yang sudah berhasil dibuat Indonesia dalam rangka menetapkan batas maritim dengan negara lain. Sejak tahun 1985, sekitar kurang lebih 36 tahun Indonesia telah meratifikasi UNCLOS 1982. Artinya Indonesia seharusnya sudah siap melaksanakan UNCLOS 1982, salah satu wujudnya dengan menyiapkan seperangkat aturan-aturan nasional dan secara konkrit Indonesia "seharusnya" sudah memiliki batas-batas yang pasti dengan negara-negara lain. Intinya bahwa Indonesia harus segera menetapkan batas wilayah yang termasuk dalam wilayah kedaulatan Negara Indonesia dan batas wilayah yang termasuk wilayah yurisdiksi Negara Indonesia, kemudian ditindaklanjuti dengan penetapan batas maritim dengan negara lain, salah satu dengan Negara Palau.

Salah satu batas maritim dengan negara tetangga yang belum selesai ditetapkan adalah batas maritim Indonesia dengan Palau. Palau berada di sebelah Timur Laut Indonesia, di sebelah Utara Papua. Palau adalah negara federal kepulauan dengan jumlah total luas daratan berkisar $500 \mathrm{~km} 2$. Palau terdiri dari beberapa pulau, di antaranya adalah Pulau Babelthuap dengan Ibukota Koror (Hartono, 2015). 
Indonesia dan Palau berbatasan maritim langsung dengan ZEE dan Landas Kontinen (LK) di perairan sekitar Laut Halmahera dan Samudra Pasifik. Kedua negara saat ini tengah merundingkan penetapan batas ZEE, sedangkan batas LK akan dirundingkan setelah penetapan batas ZEE kedua negara telah selesai. Menurut Patmasari et al. (2016) kedua negara masih berbeda posisi terkait metode delimitasi yang akan digunakan dalam mengkonstruksi garis batas ZEE kedua negara, yaitu:

1. Indonesia menerapkan metode proporsionalitas atas penarikan garis sama jarak berdasarkan relevant circumstances, di antaranya keberadaan pulau dan fitur geografis lain, luas pulau, perbedaan panjang garis pangkal.

2. Palau menerapkan metode sama jarak (equidistance).

Title 27 Palau Nation Code, Palau telah menetapkan bahwa luas laut teritorial mereka memiliki lebar sejauh 12 mil dari garis pangkal. Palau juga memiliki zona perikanan yang diperluas (Extended Fishery Zone), berada di luar dan berbatasan dengan zona perikanan eksklusif, yang lebarnya 200 mil laut diukur dari garis pangkal. (Hartono, 2015)

Negara Palau menarik garis zona perikanan yang diperluas (Extended Fishery Zone) mereka sejauh 200 mil laut yang akan secara otomatis sesuai dengan rezim ZEE, maka akan memungkinkan terjadinya tumpang tindih antara ZEE milik Indonesia dengan Extended Fishery Zone milik Palau. Oleh karena itu, perlu diadakan perjanjian antara kedua negara untuk menentukan garis batas maritim yang berupa ZEE, agar terdapat kepastian hukum bagi kedua negara. Selain itu dengan adanya kejelasan mengenai batas maritim yang sudah disepakati antara dua negara akan menjamin adanya penegakan hak berdaulat dan hukum di laut, untuk kebebasan pengelolaan sumber daya alam, serta pengembangan ekonomi kelautan bagi suatu negara.

Palau mengklaim bahwa negaranya merupakan negara kepulauan. Pada Konsepsi Penetapan Batas Maritim Indonesia dengan Palau, Kemenhan menjelaskan bahwa berdasarkan konstitusi tahun 1979, Palau memiliki yurisdiksi dan kedaulatan pada Perairan Pedalaman dan Laut Teritorialnya sampai 200 mil laut, diukur dari garis pangkal kepulauan yang mengelilingi kepulauan Palau. Sebagai negara yang terdiri dari beberapa pulau, Palau diperbolehkan menarik garis pangkal lurus kepulauan jika memenuhi aturan pada UNCLOS Pasal 47 tentang garis pangkal lurus kepulauan. Namun di dalam tabel klaim yurisdiksi maritim UNCLOS 1982, Palau bukan termasuk dalam negara kepulauan. Hal ini akan menjadikan adanya 3 (tiga) perbedaan luas ZEE akibat dari perbedaan penggunaan garis pangkal yang akan digunakan Palau untuk menentukan batas ZEE yang bertumpang tindih dengan Indonesia. Antara Indonesia dan Palau belum terbentuk hubungan bilateral yang baik. Hal ini mengakibatkan masih sedikit terselenggaranya pertemuan antara kedua negara tersebut. Sehingga untuk melakukan kesepakatan penetapan batas maritim antara kedua negara mengalami kendala, penetapan batas maritim merupakan hal yang sangat vital untuk memperjelas kawasan maritim yang dimiliki suatu negara, sehingga dalam kondisi seperti ini Indonesia tetap perlu mengupayakan kejelasan batas maritim yang dilandasi adanya dasar hukum dan metode yang tepat dalam rangka melakukan delimitasi batas maritim agar menghasilkan batas yang adil bagi kedua negara sesuai dengan UNCLOS 1982. Batas-batas ZEE Indonesia di segmensegmen sebagaimana telah disampaikan di atas Indonesia telah berhasil menyelesaikan beberapa garis batas maritim baik penetapan batas wilayah kedaulatan maupun penetapan batas wilayah yurisdiksi di laut, akan tetapi masih ada beberapa bagian daerah yang berbatasan dengan Indonesia yang belum jelas garis batasnya dengan negara lain, termasuk Palau. Oleh karena itu, dasar hukum dan metode yang telah berhasil digunakan Indonesia dapat dipergunakan sebagai acuan dan tentunya dengan menyesuaikan kondisi yang ada di lapangan. 
Fenomena di atas menimbulkan berbagai permasalahan yang perlu untuk dilakukan penelitian. Pertama, karena Indonesia sebagai negara yang luas wilayah lautnya dan tidak diragukan sumber daya hayati yang terdapat di dalamnya, maka batas maritim di ZEE Indonesia yang berbatasan dengan Palau harus segera diupayakan.

\section{Rumusan Masalah}

Atas dasar latar belakang tersebut, kiranya perlu ditelaah lebih jauh beberapa pertanyaan kunci sebagai rumusan masalah dalam penelitian ini, yaitu:

1. Kendala-kendala apa saja yang menjadi penghambat, sehingga perjanjian antara Indonesia dan Palau tentang garis batas ZEE belum selesai secara menyeluruh?

2. Upaya-upaya dan langkah-langkah apa saja yang bisa dilakukan untuk menyelesaikan perjanjian tentang penetapan garis batas ZEE antara Indonesia dan Palau?

\section{METODE PENELITIAN}

Penelitian ini menggunakan penelitian normatif. Jenis data yang digunakan adalah data sekunder, yang berupa peraturan-peraturan, baik yang sifatnya nasional maupun internasional. Di samping itu, digunakan juga buku/artikel yang terkait dengan penelitian ini, termasuk kamus, media massa dan internet. Dalam rangka untuk melengkapi penelitian ini, maka akan digunakan data primer, penggunaan data primer bertujuan untuk melengkapi dan mengecek kesesuaian data sekunder.

Pendekatan yang utama dalam penelitian ini adalah dengan pendekatan undang-undang (statute approach) dilakukan dengan menelaah semua undang-undang dan regulasi yang bersangkut paut dengan isu hukum. Pendekatan undang-undang ini untuk menelaah adanya konsistensi dan kesesuaian substansi muatan undang-undang dengan mempelajari ontologis lahirnya undangundang, landasan filosofis undang-undang dan ratio legis dari ketentuan undang-undang. (Marzuki, 2007) Menurut Soekanto dan Mamudji (2003), di dalam penelitian hukum normatif, penelitian terhadap asas-asas hukum dilakukan terhadap kaidah-kaidah hukum, yang patokanpatokan berperilaku atau bersikap tidak pantas, Penelitian tersebut dapat dilakukan (terutama) terhadap bahan hukum primer dan bahan hukum sekunder, sepanjang bahan-bahan tadi mengandung kaidah hukum.

Dalam penelitian hukum normatif pengkajian terhadap kaidah hukum saja belum cukup, sehingga perlu kajian lebih lanjut pada aspek sistem hukumnya. Sistem merupakan tatanan atau kesatuan yang utuh yang terdiri dari bagian-bagian atau unsur-unsur yang saling berkaitan erat satu sama lain yaitu kaidah atau tentang pernyataan apa yang seharusnya, sehingga sistem hukum merupakan sistem normatif (Mertokusumo, 2001). Pada penelitian ini, sistem hukumnya dengan menggabungkan peraturan-peraturan yang terkait dengan perbatasan maritim di ZEE Indonesia dengan negara lain sebagai satu kesatuan serta peraturan yang melandasinya. Proses menganalisis data dilakukan secara berbarengan dengan proses pengumpulan data.

\section{HASIL DAN PEMBAHASAN}

\section{Kendala-kendala penghambat perjanjian antara Indonesia dan Palau tentang garis batas} ZEE.

Diterimanya rezim ZEE memberikan perluasan yurisdiksi dan memberikan posisi yang kuat sekaligus memberikan keuntungan secara ekonomis terhadap negara-negara pantai untuk memperoleh hak berdaulat guna memanfaatkan sumber daya alam hayati khususnya sumber daya perikanan yang ada di ZEE. Dikatakan memberikan keuntungan secara ekonomis karena diperkirakan 90 (sembilan puluh) persen dari jumlah tangkapan ikan secara komersial dilakukan di ZEE (Vicuna, 1984; Van Steenis, 2002). 
Pengaturan tentang ZEE dalam UNCLOS 1982 terdapat dalam Part V, yang terdiri dari 21 articles, dan 15 articles dari 21 articles mengatur mengenai perikanan yang meletakkan dasar-dasar dan prinsip-prinsip bagi konservasi dan eksploitasi perikanan oleh negara pantai dan akses atau surplus perikanan bagi negara lain. Adapun pengertian ZEE menurut Article 57 (U.N. Doc , 1982), sebagai berikut: "an area beyond and adjacent to the territorial sea and shall not extend beyond 200 nautical miles from the baselines from which the breadth of the territorial sea is measured", sepanjang tidak berbatasan langsung dengan pantai negara lain pada jarak 200 mil laut tersebut.

Gambar 1.

Peta Perbatasan Wilayah Laut antara Indonesia Dengan Negara-negara Tetangga

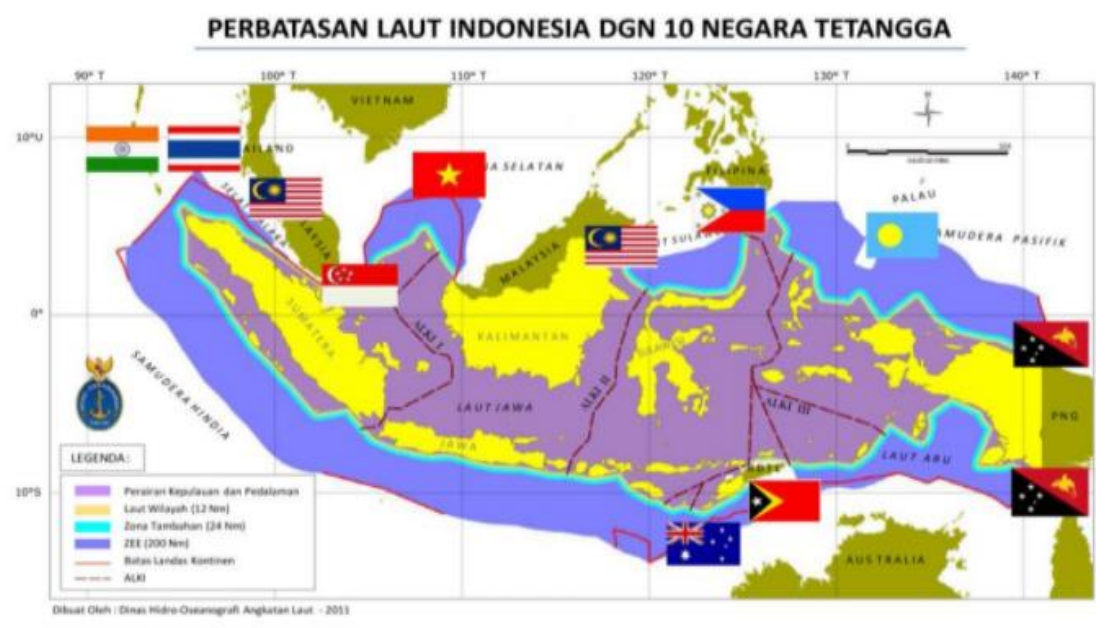

Sumber Gambar: Indriati Kusumawardhani dan Arie Afriansyah, 2019

Selesainya Konferensi Hukum Laut III, dengan diadopsinya UNCLOS 1982 (Suwardi \& Kurnia, 2019) sebagaimana telah disebutkan sebelumnya, Indonesia kemudian menjadi Negara yang memiliki luas wilayah teritorial yang besar, di mana laut bebas yang berada di antara 17.000 pulaupulau milik Indonesia berubah status menjadi perairan kepulauan (archipelagic waters) dan terbentuk "sabuk" perairan teritorial (territorial water) yang mana semuanya berada dalam kedaulatan nasional Indonesia (Oegroseno, 2012). Upaya diplomasi Indonesia juga memperkuat pemahaman atas pentingnya hukum laut internasional yang tidak saja menjadikan Indonesia sebagai negara kepulauan tetapi juga sebagai dasar bagi Indonesia untuk melaksanakan eksploitasi sumber daya maritim secara berkelanjutan. Dengan alasan untuk memperjelas batas - batas maritim dengan negara tetangga, yang tidak saja bertujuan untuk menegaskan batas maritim Indonesia namun juga bagi eksploitasi sumber daya alam laut, maka Pemerintah Indonesia melaksanakan diplomasi batas maritim (maritime border diplomacy) (Kusumawardhani \& Afriansyah, 2019). Berkaitan dengan batas maritim antara Indonesia dan Palau sampai saat ini belum tercapai kata sepakat. Batas ZEE Indonesia berada pada posisi sebelum Pulau Tobi dan Karang Helen yang merupakan pulau milik Palau dan Palau menggunakan metode sama jarak. Apabila metode sama jarak diterapkan oleh Palau maka akan terjadi tumpang-tindih dengan ZEE Indonesia. Padahal ketentuan UNCLOS 1982 mengatur bahwa batas wilayah yurisdiksi seperti halnya ZEE menggunakan prinsip keadilan. Di samping itu mengacu kepada putusan Arbitrase Filipina dan RRC ditetapkan bahwa pulau-pulau kecil seperti Pulau Tobi dan Karang Helen tidak memiliki hak untuk mendapatkan ZEE. Hal inilah yang menjadi kendala karena ada perbedaan persepsi. 


\section{Upaya-upaya yang Dapat Dilakukan Dalam Rangka Penetapan Garis Batas ZEE}

Upaya Indonesia dalam rangka menetapkan batas maritim dengan negara lain yang berbatasan dengan Indonesia telah dilakukan sejak tahun 1969 hingga berlakunya UNCLOS 1982, Indonesia telah berhasil menyepakati batas maritim dengan negara tetangga. UNCLOS 1982 mengatur 3 (tiga) jenis batas maritim, yaitu laut teritorial, landas kontinen, dan zona ekonomi eksklusif (ZEE). (U.N. Doc , 1982) Adapun menurut Patmasari et al. (2016) berbagai Perjanjian yang telah berhasil disepakati adalah sebanyak 18 Perjanjian Batas Maritim, yaitu:

1. Indonesia - Malaysia:

a. Landas Kontinen, 27 Oktober 1969, dengan Keppres Nomor 89 Tahun 1969.

b. Laut Teritorial di Selat Malaka, 17 Maret 1970, dengan Undang - Undang Nomor 2 Tahun 1971.

2. Indonesia - Singapura

a. Laut Teritorial di Selat Singapura, 25 Mei 1973, dengan Undang - Undang Nomor 7 Tahun 1973.

b. Laut Teritorial di Selat Singapura bagian barat, 10 Maret 2009, dengan Undang Undang Nomor 4 Tahun 2010.

c. Laut Teritorial di Selat Singapura bagian timur, 3 September 2014, Undang - Undang Nomor 1 Tahun 2017.

3. Indonesia - Australia

a. Dasar Laut Tertentu, 18 Mei 1971, dengan Keppres Nomor 42 Tahun 1971.

b. Dasar Laut Tertentu di Wilayah Laut Timor dan Arafura, Tambahan terhadap Persetujuan tanggal 18 Mei 1971 dengan Keppres Nomor 66 Tahun 1972.

c. Garis - garis Batas Tertentu antara Indonesia dan Papua Nugini, 12 Februari 1973, dengan Undang - Undang Nomor 6 Tahun 1973.

d. Zona Ekonomi Eksklusif dan Dasar Laut Tertentu, 14 Maret 1997 (belum diratifikasi)

4. Indonesia - Thailand

a. Landas Kontinen di Bagian Utara Selat Malaka dan di Laut Andaman, 17 Desember 1971 dengan Keppres Nomor 21 Tahun 1972.

b. Dasar Laut di Laut Andaman, 11 Desember 1975 dengan Keppres Nomor 1 Tahun 1977.

5. Indonesia - India

a. Garis Batas Landas Kontinen, 8 Agustus 1974 dengan Keppres Nomor 51 Tahun 1974.

b. Perpanjangan Garis Batas Landas Kontinen 1974, 14 Januari 1977 dengan Keppres Nomor 26 Tahun 1977.

6. Indonesia - India - Thailand

a. Trijunction Point dan Garis Batas dari Garis-garis Batas Tertentu di Laut Andaman, 22 Juni 1978 dengan Keppres Nomor 24 Tahun 1978.

7. Indonesia-Vietnam

a. Garis Batas Landas Kontinen di Utara Pulau Natuna, 26 Juni 2003 dengan Undang Undang Nomor 18 Tahun 2007.

8. Indonesia - Filipina

a. Garis Batas ZEE di Laut Sulawesi, 23 Mei 2014, masih dalam proses ratifikasi.

9. Indonesia - PNG

a. Garis Batas Landas Kontinen, 13 Desember 1980 dengan Keppres Nomor 21 Tahun 1982. 
Gambar 2.

\section{Statistik Perundingan Batas Maritim Indonesia}

\section{Statistik Perundingan Batas Maritim}

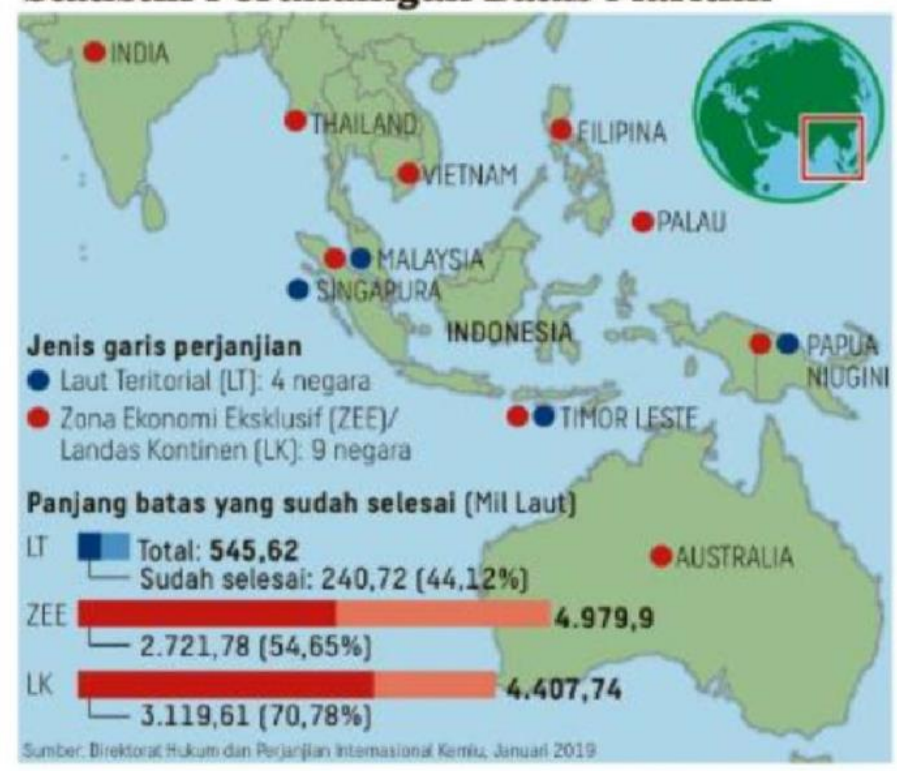

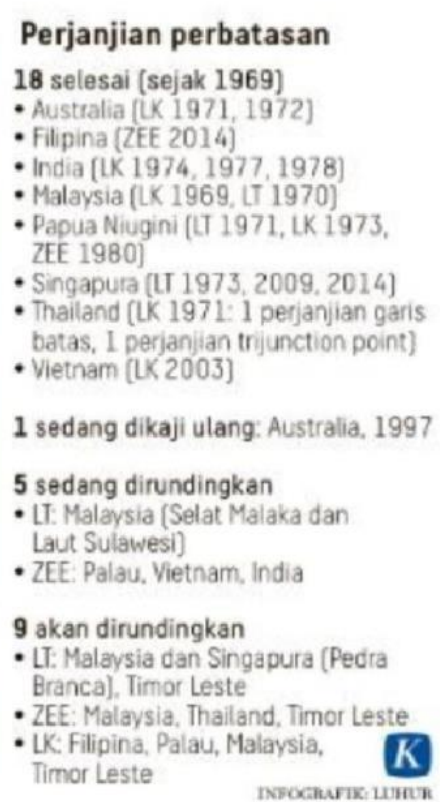

Perjanjian perbatasan

stia [LK 1971, 1972]

- Filipina (ZEE 2014

- Papua Niugini [LT 1971, LK 1973, ZEE 1980]

Sngapura If $1973,2009,2014$

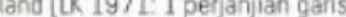

Vietnam (LK2003)

1 sedang dikaji ulang: Australia, 1997

5 sedang dirundingkan

- Halarsia (Selat Malaka dan

Laut Sulawesi

9 akan dirundingkan

LI: Malaysia dan Singapura (Pedra

Branca), Timor Leste

LK: Filipina, Palau, Malaysia, $\quad K$

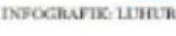

Berdasarkan data di atas, perundingan perbatasan maritim yang masih berlangsung adalah sebagai berikut: 1 (satu) Perjanjian RI - Australia yang sedang dikaji ulang (Perjanjian tahun 1997); 5 (lima) Perundingan yaitu RI - Malaysia mengenai laut teritorial di wilayah Selat Malaka dan Laut Sulawesi dan ZEE antara RI - Palau, RI - Vietnam, dan RI - India; dan 9 (sembilan) usulan yang akan dirundingkan, yaitu laut teritorial RI - Malaysia dan Singapura (Pedra Branca), RI - Timor Leste, ZEE antara RI - Malaysia, RI - Thailand, RI - Timor Leste; dan Landas Kontinen antara RI - Filipina, RI - Palau, RI - Malaysia, dan RI - Timor Leste.

Perundingan yang dilakukan Indonesia dengan Palau belum tercapai kata sepakat, hal ini terkendala karena adanya perbedaan persepsi dalam menafsirkan batas maritim ZEE. Adanya dua pulau yaitu Pulau Tobi dan Karang Helen yang merupakan milik Palau mempunyai ZEE, sedangkan mengacu pada putusan Arbitrase Filipina dan RRC, pulau-pulau kecil tidak berhak atas ZEE. Padahal kedua pulau tersebut mempunyai batas yang tidak jauh dengan batas ZEE, artinya apabila ZEE kedua pulau tersebut diperhitungkan mengakibatkan tumpang-tindih.

Berdasarkan hal tersebut, Indonesia dapat mengupayakan dengan menerapkan ketentuan UNCLOS 1982 Bab XV, yaitu sambil menunggu perjanjian final maka Indonesia dan Palau dapat memanfaat sumber daya hayati di wilayah perbatasan tersebut. Selanjutnya, upaya yang dapat dilakukan Indonesia dalam penyelesaian batas maritim dengan Palau dapat mengacu kepada peraturan-peraturan seperti putusan arbitrase dan praktik-praktik yang telah dilakukan Indonesia dan berhasil menetapkan batas maritim ZEE dengan negara lain.

\section{KESIMPULAN DAN SARAN}

1. Indonesia dan Palau, harus melihat dan sekaligus menerapkan aturan yang mengakomodir kepada kepentingan dan kebutuhan masyarakat internasional. Hal ini karena sudah ada ketentuan yang sifatnya mengatur kepentingan dan kebutuhan masyarakat internasional, yaitu UNCLOS 1982. Apabila dilihat dari perkembangan sejarah terbentuknya UNCLOS 1982 tersebut, maka tidak terlepas dari tindakan-tindakan yang sifatnya sepihak yang 
dilakukan oleh negara-negara yang dimulai dari negara Amerika, kemudian negara-negara yang tergabung dalam Asian African Legal Consultative Committee bahkan Indonesia yang menerapkan pelebaran wilayah lautnya dalam rangka mencadangkan sumber daya alam hayati untuk kebutuhan dan kesejahteraan rakyatnya. Upaya ini di dalam hukum internasional khususnya pelebaran wilayah yurisdiksi dikatakan sebagai kebiasaan internasional, yaitu suatu kebiasaan yang masuk di dalam sumber hukum internasional. Selanjutnya dalam rangka untuk menjamin adanya kepastian hukum dan adanya kejelasan dalam pembuktian apabila suatu negara melakukan tindakan lebih lanjut dan terkait dengan hak dari negara lain, sehingga akan jelas konsekuensinya maka dituangkan ke dalam bentuk perjanjian internasional, yaitu UNCLOS 1982. Artinya UNCLOS 1982 merupakan kesepakatan internasional dan menjadi dasar bagi masyarakat internasional apabila hendak menerapkan lebar wilayah lautnya dan wilayah laut yang berhadapan/berdampingan dengan negara lain.

Perjanjian antara Indonesia dan Palau belum dapat diwujudkan karena adanya perbedaan persepsi mengenai batas maritim khususnya batas ZEE antara kedua negara tersebut. UNCLOS 1982 telah mengatur delimitasi maritim namun dalam implementasinya UNCLOS 1982 menyerahkan kepada kesepakatan dari negara-negara yang terkait. Hal inilah yang menjadi kendala.

2. Adapun upaya yang dapat dilakukan Indonesia dalam penyelesaian batas maritim dengan Palau dapat mengacu kepada peraturan-peraturan termasuk putusan badan-badan peradilan, di samping itu praktik-praktik yang pernah dilakukan dan berhasil dilakukan Indonesia dalam rangka menetapkan batas maritim dalam hal batas ZEE dengan negara lain. Upaya sementara, kedua negara sambil menunggu perjanjian final dapat mengikuti prosedur penyelesaian sengketa sesuai Bab XV UNCLOS 1982 yaitu kedua negara baik Indonesia maupun Palau dapat memanfaatkan sumber daya alam hayati di wilayah perbatasan tersebut.

\section{Ucapan Terima Kasih (Acknowledgement)}

Sehubungan dengan telah dilaksanakannya kegiatan penelitian mengenai "Batas Maritim Indonesia dan Palau di Zona Ekonomi Eksklusif", Tim Penelitian Fakultas Hukum Universitas Tarumanagara mengucapkan terima kasih kepada Lembaga Penelitian dan Pengabdian Kepada Masyarakat Universitas Tarumanagara yang telah memberi izin kepada Tim Peneliti Fakultas Hukum Universitas Tarumanagara untuk mengadakan penelitian.

\section{REFERENSI}

Hartono, R. (2015). Penentuan batas maritim Indonesia dengan Palau berdasarkan Unclos 1982. Undergraduate Thesis, Institut Teknologi Surabaya, Surabaya.

Kusumawardhani, I., \& Afriansyah, A. (2019). Kebijakan kelautan Indonesia dan diplomasi maritim. Jurnal Kertha Patrika, 41 (3), 266.

Mertokusumo, S. (2001). Penemuan Hukum Sebuah Pengantar. Liberty.

Oegroseno, A. H. (2012). Maritime Border Diplomacy. Brill Nijhoff. https://doi.org/10.1163/9789004230941_005.

Patmasari, T., Artanto, E., \& Rimayanti, A. (2016). Perkembangan Terakhir Batas Maritim Indonesia Dengan Negara Tetangga. Seminar Nasional Peran Geospasial dalam Membingkai NKRI. Pusat Pemetaan Batas Wilayah - Badan Informasi Geospasial, Cibinong.

Peter, M. M. (2007). Penelitian Hukum. Kencana.

Soekanto, S., \& Mahmudji, S. (2003). Penelitian Hukum Normatif: Suatu Tinjauan Singkat. Rajawali Pers. 
Suwardi, Sri, S., \& Kurnia, I. (2019). Hukum Perjanjian Internasional. Sinar Grafika.

United Nations Convention on The Law of The Sea. (1982).

Van Steenis, J.. (2002). Pirates as poachers: International fisheries law and the bluefin tuna. Capital University Law Review. https://heinonline.org/HOL/LandingPage?handle=hein.journals/capulr29\&div=27\&id=\& page $=$

Vicuna, F. O. (1984). The Exclusive Economic Zone, A Latin American Perspective. Westview Press. 